\title{
INTERNATIONAL POLICY
}

\section{FRAMEWORK}

\author{
Norbert LeONHARDMAir, PAUl Herbinger \& \\ MARION NEUNKIRCHNER \\ Vienna Centre for Societal Security, Vienna, Austria. \\ E-mail: norbert.leonhardmair@vicesse.eu,paul.herbinger@vicesse.eu, \\ marion.neunkirchner@vicesse.eu
}

\begin{abstract}
This chapter describes the international policy framework and efforts made on the international and European level to further the fight against violence against women and domestic violence. The respective national legal frameworks and organisational context of front-line responder services are discussed in-depth in the following chapters. The IMPRODOVA project followed a bottom-up approach in its investigation of ground-level practices of cooperation of frontline responder services, which are, however, only meaningfully understood when interpreted in the governing national legal and policy framework. While numerous international policy documents relate to domestic violence, the ratification of the Convention on Preventing and Combating Violence against Women and Domestic Violence in 2011 represents perhaps the most significant attempt to institute a comprehensive policy framework in this field. The "Istanbul Convention" includes the first legally binding, international, and wide-reaching set of norms to combat violence against women in general and domestic violence specifically.

Keywords: domestic violence, international policy framework, Istanbul convention, first responders, police
\end{abstract}




\section{Introduction}

This chapter describing the international policy framework and efforts made by on international and European level to further the fight against violence against women and domestic violence, sets the stage for the in-depth country reports (Chapter 3), which outlines the respective national legal frameworks and organizational context of frontline responder services. ${ }^{1}$

The IMPRODOVA project followed a bottom-up approach in its investigation of ground-level practices of cooperation of frontline responder services, which are, however, only meaningfully understood when interpreted in the governing national legal and policy framework. Nevertheless, innovative and good local and organizational practices often are found not just enabled by, but in spite of the governing legal and procedural framework. The interplay of international (minimum) standards and local practices, mediated via the national legal framework, cannot be understood as a one-way trickling top-down prescription of requirements, which are nationally transposed and locally implemented. Policy making on an international level even took note of progressive and ground-breaking practices inspired by advocacy groups formed by frontline responder organisations. On the other hand, we find examples of countries that have not formally ratified international conventions but exceed in their national and local commitment to combat Domestic Violence.

\section{Overview of international conventions, declarations, and treaties combatting Violence against Women and Domestic Violence by different $\mathrm{UN}$ bodies and the $\mathrm{COE}^{2}$}

- 1979: Convention on the Elimination of all Forms of Discrimination against Women (CEDAW)

\footnotetext{
${ }^{1}$ A more detailed discussion of the translation of international policies at the national level can be found in Herbinger et. al. (2020)

${ }^{2}$ Related policies addressing Violence Against Women in general, protection of women migrant workers, human trafficking of women and girls, cultural practices affecting women's health, gender equality, sexual violence against women (incl. in conflict, as in 1993 with the establishment of the International Criminal Tribunal for the former Yugoslavia) and links to reproductive health are not listed without reference to domestic violence. A comprehensive overview of UN conventions, GA resolutions, SG reports and studies, and HRC resolutions can be found at the homepage of UN Women (2021) Violence Against Women [Online] URL:

https://www.un.org/womenwatch/daw/vaw/v-hrc.htm (accessed 2021-07-23).
} 
- 1985: General Assembly Resolution on Domestic Violence

- 1989: Convention on the Rights of the Child

- 1993: Vienna Declaration and Programme of Action

- 1993: Declaration on the Elimination of Violence against Women

- 1994: Appointment of the Special Rapporteur on violence against women, its causes and consequences

- 1995: Beijing Platform for Action

- 1996: United Nations Trust Fund in Support of Actions to Eliminate Violence against Women

- 1999: International Day for the Elimination of Violence Against Women/ 16 days of Activism

- 2006: Secretary-General's In-Depth Study on All Forms of Violence against Women

- 2008: UN launch of UNiTE campaign to End Violence against Women

- 2010: HRC Resolution on accelerating efforts to eliminate all forms of violence against women

- 2011: COE Convention on preventing and combating violence against women and domestic violence

The 1990s saw what was arguably the first major surge of international policy frameworks and documents addressing Violence Against Women in general, and Domestic Violence in particular. Against the background of earlier initiatives and institutions such as the United Nations Convention on the Elimination of Discrimination against Women (CEDAW) adopted in 1979 (United Nations); the 1985 UN General Assembly Resolution on Domestic Violence; and the 1989 UN Convention on the Rights of the Child (CRC); the United Nations, Council of Europe, and European Union began drafting documents intended to provide guidance and legal grounds for the national responses to Domestic Violence. While the CEDAW did not yet include references to violence against women, focusing instead on the legally binding imperative to ensure equal rights between the sexes, its acknowledgement of the structural inequality experienced by women formed the entry point for ground-breaking resolutions relating specifically to the topic of violence. The United Nations General Assembly adopted the first of these, the Declaration on the Elimination of Violence against Women (A/RES/48/104Resolution 48/104), saw its ratification in 1993. It has been 
furthered in 2004 under the same title by Resolution A/RES/58/147 by the UN General Assembly. In 1993, the appointment of a Special Rapporteur on violence against women was requested in the Vienna Declaration and Programme of Action (United Nations human rights,1993), which was established in the World Conference on Human Rights, recognizing violence against women as a human rights violation. Others followed, such as the 1995 Beijing Declaration and Platform for Action (United Nations, 1995), which included the objective to end all forms of violence towards women as well as practical measures to be taken by states, international organizations and NGOs. Since 2003 three resolutions prepared by the Secretary-General on an in-depth study on all forms of violence against women have been launched ${ }^{3}$.

The 2010 resolution of the UN Human Rights Council (HRC) committed to accelerating efforts to eliminate all forms of violence against women. In 2015, countering Violence against Women was included in the Sustainable Development Goals. The UN Human Rights Council (HRC) has also passed several resolutions on eliminating discrimination and violence against women (UN Women, n.d). Frequently relating to these UN resolutions, the Council of Europe, as well as the European Union adopted several instruments to combat this form of violence, pertinent examples being: the Council of Europe Recommendation on the Protection of Women Against Violence (REC(2002)5), (Committee of Ministers, 2002), the 2005 Convention addressing human trafficking (Council of Europe, 2005) and the Istanbul Convention on Preventing and Combatting Violence against Women and Domestic Violence (Istanbul 11/05/2011). Similarly, Directive 2004/81/EC and Directive 2011/36/EU (European Parliament \& of the Council, 2011) specifically targeted Violence against Women in the context of human trafficking, while the Victims of Crime Directive of 2012 (Directive (2012/29/EU)) (European Parliament \& Council of the European Union, 2012) provided minimum standards on the rights, support and protection of victims in general.

Since 2012, the UN General Assembly has adopted resolutions on the intensification of efforts to eliminate all forms of violence against women every two years, in addition to reports of the Special Rapporteur on violence against women. ${ }^{4}$

\footnotetext{
${ }^{3}$ UN (2021) Work of the General Assembly on violence against women; https://www.un.org/womenwatch/daw/vaw/v-work-ga.htm.

${ }^{4}$ UN Women (2021) Global norms and standards: Ending violence against women; https://www.unwomen.org/en/what-we-do/ending-violence-against-women/global-norms-and-standards.
} 
Notable achievements were establishing the UN International Day for the Elimination of Violence against Women (25 November) in 1999, which coincided with the UN acknowledging and taking part in the "16 Days of Activism" established by the international women's movement already in 1991.

\section{Victims of Crime Directive 2012/29/EU}

Victims of Crime Directive (2012/29/EU) (European Parliament \& Council of the European Union, 2012) outlines frameworks specific to the implementation of national strategies to combat Violence against Women and Domestic Violence. IMPRODOVA's focus on the protection of Victims of Domestic Violence lies inter alia: on the implementation of Victim's support services (Art. 8 and 9), on training of practitioners (Art. 25), and cooperation and coordination of services (Art. 26). As large section of the Victims of Crime Directive Articles relates strongly to the Istanbul Convention. However, the discussions in the following sections will relate only to compliance to the latter in an effort to reduce complexity.

\section{The Convention on Preventing and Combating Violence against Women and Domestic Violence (Istanbul Convention)}

While numerous international policy documents (only a selection of which have been outlined above) relate to the topic of Domestic Violence, the ratification of the Convention on Preventing and Combating Violence against Women and Domestic Violence in 2011 represents perhaps the most important attempt to institute a comprehensive policy framework in this field. The "Istanbul Convention" includes the first legally binding, international and wide-reaching set of norms to combat Violence against Women in general, and Domestic Violence specifically. Across twelve chapters and eighty-one articles, the Convention entails several detailed measures in the areas of policy, prevention, provision, protection and prosecution, as well as comprehensive definitions for each of these forms of violence.

Violence against Women "is understood as a violation of human rights and a form of discrimination against women and shall mean all acts of gender-based violence that result in, or are likely to result in, physical, sexual, psychological or economic harm or suffering to women, including threats of such acts, coercion or arbitrary deprivation of liberty, whether occurring in public or in private life". (Art 3 Sec a) This definition makes it possible to address both physical and psychological 
violence, as well as forced marriages, genital mutilation, forced sterilizations, rape, and sexual harassment. Article 2 further encourages the application of the Convention to victims of Domestic Violence (Art 2 Sec 2), which is defined as "all acts of physical, sexual, psychological or economic violence that occur within the family or domestic unit or between former or current spouses or partners, whether or not the perpetrator shares or has shared the same residence with the victim". (Art $3 \mathrm{Sec}$ B) While the application of the Convention to all forms of Violence against Women (Art 2 Sec 1) both in times of peace and in situations of armed conflict (Art 2 Sec 3) are legally binding, the inclusion of Domestic Violence within its scope remains a recommendation. The peculiarity of this differentiation shall be addressed in a later section.

Among numerous detailed measures to combat Violence against Women, the Istanbul Convention includes norms on risk assessment and risk management, outlining the imperative to "take necessary legislative or other measures" (Art $51 \mathrm{Sec}$ 1) to ensure that relevant authorities evaluate the risk of lethality, seriousness of the situation as well as the risk of repeated violence. Chapter IV includes articles outlining the imperative to provide specialized support for victims such as the proper provision of information (Art 19), assistance in individual/collective complaints (Art 21), specialist support services (Art 22), shelters (Art 23), as well as support and encouragement for reporting (Art 27). Further chapters extend the purview of the convention, for example, to areas of migration and asylum (Chapter VII), international cooperation (Chapter VIII), prevention (Chapter III) and substantive law (Chapter V).

In that, the Istanbul Convention outlines policy guidelines and recommendations across the whole cycle of intervention from prevention, intervention to prosecution.

\section{From international policies to national implementation and organisational practices}

IMPRODOVA approached the exploration of the existing national policy framework via the National Action Plans (NAP) as an entry point. The review of the countries showed that those vary between countries and over time with respect to the specificity of their focus as NAP against violence, against violence against women, against domestic violence. The NAPs requested them to organize and 
demonstrate their policy response to Domestic Violence; however, the reference to international guidelines and policies within them is very heterogeneous, as to which international treaties, conventions, and declarations are mentioned or whether there are any references to them at all. The NAPs served as a chain link between international policies, the national legal framework and the local and organisational implementation of guidelines in investigating the gap between formal provisions and organisational practices.

The definition of DV in the Istanbul Convention is often used as the leading definition of DV within the country's National Action Plans (NAPs). Within this framework, the definition is based on a gender-related violence concept, mainly understood as violence against women and children. Differences between frontline responder's definitions were not collected in all partner countries, since in most cases, all three FLR sectors use the same definition of DV according to the respective national policies (NAP). However, there is little awareness among ground-level practitioners on international policies or national policy definitions in practice.

Generally, the cross-national comparison is a complex undertaking, particularly in the context of DV, as different countries use distinctive concepts and varied definitions of DV. Furthermore, these distinctive concepts caused the phenomenon itself to appear in a different light in each context. Intimate partner violence (IPV), domestic violence (DV) and family violence (FV) are the main terms that are used across all countries to describe this phenomenon.

A further gap can be demonstrated by the definition of "high impact" DV cases, which predominantly are not covered by a specific sub-definition of DV within national policies. While in most countries many different legal provisions apply to DV cases, Portugal and the UK as the only two countries among the selected European Member States (MS), which have defined DV as a separate criminal offence.

The country-specific differences between legal structures, policies, and national strategies against DV cause FLRs to cooperate in different ways, enable specific definitions of DV, and use different risk assessments. In most partner countries, however, the Istanbul Convention (IC) is central in implementing national policies. 
As of 2021, the convention has been ratified in all partner countries except Hungary and the UK (Council of Europe, 2018).

\section{References}

Committee of Ministers. (2002). Recommendation $\operatorname{Rec}(2002) 5$ of the Committee of Ministers to member states on the protection of women against violence. https://search.coe.int/cm/Pages/result_details.aspx?ObjectID=09000016805e2612

Council of Europe. (2014). Council of Europe Convention on preventing and combating violence against women and domestic violence. https:// rm.coe.int/168008482eCouncil\%20of\%20Europe

Council of Europe. (2005). Action against Trafficking in Human Beings. https://www.coe.int/en/web/antihuman-trafficking/about-the-convention

Council of Europe. (2018). Complete list of the Council of Europe's treaties. https://www.coe.int/en/web/conventions/full-list/-/conventions/treaty/210/signatures

European Parliament \& of the Council. (2011). Directive 2011/36/EU of the European Parliament and of the Council of 5 April 2011 on preventing and combating trafficking in human beings and protecting its victims, and replacing Council Framework Decision 2002/629/JHA, Official Journal of the European Union, (101), 1-11. https://eur-lex.europa.eu/legalcontent/EN/TXT/?qid=1566304719526\&uri=CELEX:32011L0036

European Parliament \& Council of the European Union. (2012). Directive 2012/29/EU of the European Parliament and of the Council of 25 October 2012 establishing minimum standards on the rights, support and protection of victims of crime, and replacing Council Framework Decision 2001/220/JHA. Official Journal of the European Union, (315), 57-73. https://eur-lex.europa.eu/eli/dir/2012/29/oj

Herbinger, P., Neunkirchner, M., \& Leonhardmair, N. (2020). European Legislation to Fight Domestic Violence. European Law Enforcement Research Bulletin, (20), 141-154. https://bulletin.cepol.europa.eu/index.php/bulletin/article/view/415

UN Entity for Gender Equality and the Empowerment of Women. (n.d.). Violence against women. https://www.un.org/womenwatch/daw/vaw/v-sg-study.htm

UN General Assembly. (1985). Domestic violence: resolution / adopted by the General Assembly. https://www.refworld.org/docid/3b00f00b64.html

UN General Assembly. (1989). Convention on the Rights of the Child. Treaty Series, 1577, p. 3. https://www.refworld.org/docid/3ae6b38fo.html

UN General Assembly. (1993). Vienna Declaration and Programme of Action. https://www.refworld.org/docid/3ae6b39ec.html

UN General Assembly. (2003). Elimination of domestic violence against women. https://undocs.org/pdf?symbol=en/A/RES/58/147

United Nations. (1995). Beijing Declaration and Platform of Action, adopted at the Fourth World Conference on Women. https://www.refworld.org/docid/3dde04324.html

United Nations human rights. (1979). Convention on the Elimination of All Forms of Discrimination against Women, Treaty Series, 1249, 13. https://ohchr.org/en/professionalinterest/pages/cedaw.aspx

United Nations human rights. (1993). Declaration on the Elimination of Violence against Women. https://www.ohchr.org/EN/ProfessionalInterest/Pages/ViolenceAgainstWomen.aspx 